\title{
Latîfî Tezkiresini Derkenardan Okumak: Tezkirenin Râşid Efendi Nüshasındaki Notlar Üzerine Bir İnceleme
}

\author{
Doç. Dr. Oğuzhan Şahin \\ İzmir Kâtip Çelebi Üniversitesi, Sosyal ve Beşeri Bilimler Fakültesi \\ Türk Dili ve Edebiyatı Bölümü \\ ogsahin@gmail.com
}

$\ddot{\mathrm{O} z}$

Türk tezkirecilik geleneğinin önemli metinlerinden sayılan Latîfî Tezkiresi kaleme alındığı ilk yıllardan itibaren bazı eleştirilerin hedefi olmuştur. Tezkirenin Kayseri Râşid Efendi nüshasındaki kayıtlardan anlaşıldığına göre Latîfı̂'ye dair bu eleştiriler kendi döneminde de sözde kalmamış ve tezkireyi çeşitli açılardan tamamlayıcı "notlar" olarak Râşid Efendi nüshasının derkenarlarına işlenmiştir. Bahsi geçen notlar tezkirenin bütününe yayılmış vaziyettedir. Mahiyet itibarıyla ise bu notlarda ya Latîfî tarafından tezkiredeki şairlerin tespit edilemeyen şiirlerinden örnekler verilmekte ya da çeşitli şairlere dair kimi zaman magazinsel bir tarafı da olan satır arası bilgiler sunulmaktadır. Râşid Efendi'nin derkenarlarına kaydedilmiş bu notları kimin tuttuğu kesin olarak belli değildir. Ancak tezkirenin ilk versiyonu sayılan bu nüsha üzerindeki bazı çalışmalarda notları düşen kişinin Latîfî olabileceği iddia edilmiştir. Bu yazıda Râşid Efendi nüshasındaki notlar mahiyet, muhteva, güvenilirlik, kim tarafından ve niçin tutulduğu gibi noktalarda ele alınmış ve bunlarla Latîfî Tezkiresi arasında organik bir bağ olup olmadığı hususu tartışılmıştır.

Anahtar Kelimeler: Latîfî Tezkiresi, okuyucu notları, sahh kayıtları, Kayseri Râşid Efendi nüshası, Deh Murg.

\section{Reading the Tezkere of Latifi from Its Apostil: An Evaluation on the Notes in the Tezkere's Copy of Rashid Efendi}

\begin{abstract}
The Tezkere of Latifi, which is regarded as one of the most important texts of Turkish tezkeres, has been the target of some criticism since it was appeared. According to the records in the copy of Kayseri Rashid Efendi, these criticisms about Latifi did not remain in their own time either and were written in the copy of Rashid Efendi as complementary "notes" in various aspects. The aforementioned notes are spread over the entire text. In terms of nature, he either gives examples of the poems of the poets in the controversy by Latifi, or provides inline information about various poets, sometimes including their private life information. It is not entirely clear who kept these notes that were recorded in the copy of Rashid Efendi. However, some studies on this copy, which is considered as the first version of the tezkere, claimed that the person whose notes were down may be Latifi himself. In this article, the notes in the copy of Rashid Efendi are discussed in terms of
\end{abstract}


nature, content, reliability, by whom and why they were written, and whether there is an organic connection between them and the Tezkere of Latifi.

Keywords: Tezkere of Latifi, reader notes, sahh records, copy of Kayseri Rashid Efendi, Deh Murg. 


\section{GİRIŞ}

Latîfî Tezkiresi, kaleme alındığı ilk yıllardan başlamak üzere gerek kendi döneminde gerekse günümüz literatüründe hakkında çok fazla konuşulan biyografik metinlerdendir. Tezkireye dair, birçok şairi Kastamonulu yapması, devrin önde gelen bazı şairlerini almaması, Osmanlı'nın din ve devlet büyüklerini aşağılamak için oryantalistler tarafından eskitilmiş kâğıtlara yazdırılan fake bir metin olduğu ve yazma geleneğine dikkat edilmediği için neşirlerinin problemli olduğu şeklindeki iddialar hâlâ güncelliğini korumaktadır. En başta söylemek gereklidir ki bu çalışma bahsi geçen iddiaların doğruluk yahut yanlışlıklarını tartışmak için değil, Latîfî Tezkiresi'nin, üzerine önceden de bazı sözler söylenen Kayseri Râşid Efendi Kütüphanesi 1160'ta kayıtlı nüshasındaki birtakım notları mercek altına alabilmek için kaleme alınmıştır. Bu bağlamda bahsi geçen notların kime ait olduğu, mahiyet açısından Latîfî Tezkiresi'yle nasıl bir bağının bulunduğu ve verdiği bilgiler bakımından ne derece güvenilir olduğu gibi hususlar sorgulanmaya çalışılmıştır.

Râşid Efendi nüshasına derkenar olarak düşülen bu notların kime ait olduğu çeşitli bakımlardan önemlidir. Öncelikle muhteva açısından bakıldığında -daha sonra verilecek örneklerden de görüleceği üzere- bahsi geçen notların biyografi hususunda donanımlı biri tarafından tutulduğu anlaşılmaktadır. Her ne kadar Riyâzî-yi Üskübî'nin anlatıldığı notta yer alan "Latîfi bunı idrâk u zabt itmekde kâsır oldugıçün hakîr yazdum (Râşid Efendi, yz. 1160, 80b)." türünden tahkir içeren ifadeler çok fazla göze çarpmasa da satır satır tezkire üzerinde çalışan notların sahibi bu kişinin Latîfî̀n nin muarızlarından biri olması da ihtimal dışı değildir. Şayet notları düşen kişi Latîfî̀nin eksiklerini teşhir amacı taşıyan muarız bir tezkireci/meslektaş değilse o dönem toplumunda tezkire okurlarının entelektüel profillerini tahmin noktasında bize ipucu vermektedir. Zira notların muhtevası, bunların tezkire kültüründen haberi olmayan sıradan kişiler tarafından tutulamayacağını ortaya koyar niteliktedir.

Râşid Efendi'deki bu notların neden düşüldügü ve Latîfî ile bağlantısı olup olmadığı sorgulanmadan önce bunların mahiyeti üzerinde durmak gereklidir. Bu noktada Râşid Efendi nüshasına bakıldığında, nüshanın derkenarlarında birbirine karışmış vaziyette iki tür notla karşılaşılmaktadır: Sahh kayıtları ve müstakil bir başlıkta incelenecek olan bilgi notları. ${ }^{1}$ Sahh kayıtları, tezkirenin sonraki yapraklarında da bulunmakla birlikte, Râşid Efendi nüshasının ilk 35 yaprağında daha sık göze çarpmaktadır. Derkenarlardaki bu kayıtların sahh (düzeltme) kaydı olduğunu bunların yanına koyulan sahh işaretlerinden anlamak mümkündür. Ayrıca tezkirenin genişletilmiş versiyonu -kabul edilen- Hâlet Efendi 342 numaradaki nüshada da bu kayıtların doğrudan tezkire metnine dâhil edilmesi bunların sahh olduklarını teyit etmektedir:

\footnotetext{
${ }^{1}$ Bu çalışmada "bilgi notları" kavramını ifade etmek için okuyucu notları tabiri de kullanılmıştır. Fakat bu tabirle çeşitli mahfillerde -sesli olarak- okunan hikâyelere düşülmüş notlar kastedilmemektedir. Tahkiyevî metinlere düşülen bu tarzdaki notları değerlendiren bir çalışma için bkz. (Değirmenci, 2011).
}

SEFAD, 2020; (44): 161-180 


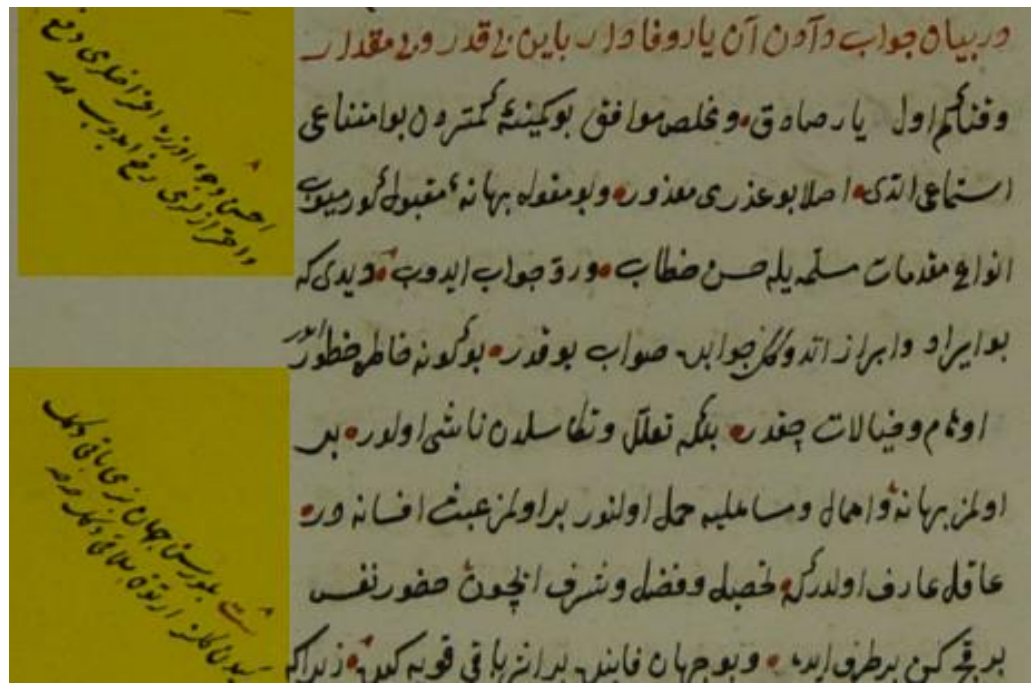

Resim-1: Râşid Efendi 1160'taki sahh kayıtlarına dair bir örnek:

Râşid Efendi, yz. 1160, 14a
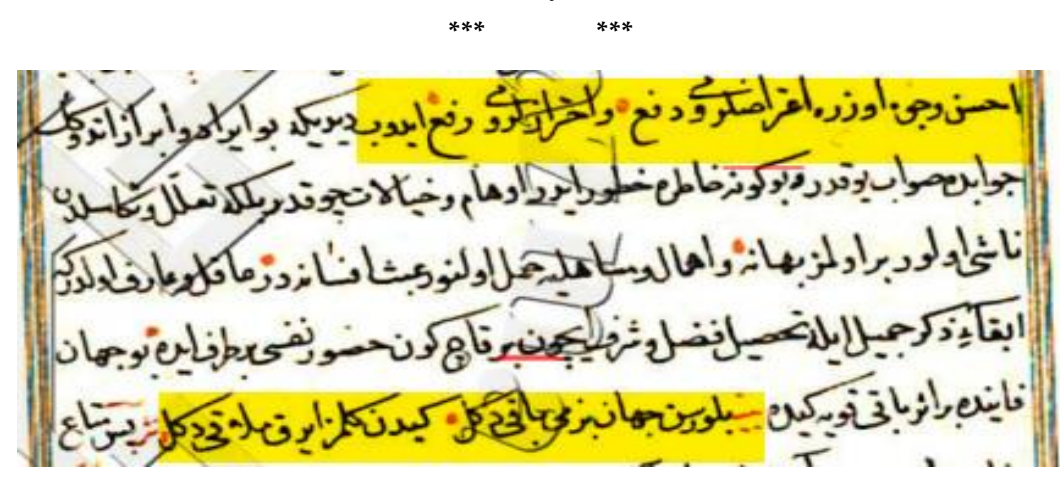

Resim-2: Yukarıdaki kaydın Hâlet Efendi 342'de tezkire metnine dâhil edilişini gösteren bir örnek:

Hâlet Efendi, yz. 342, 9b.

Râşid Efendi'deki sahh kayıtlarının tezkirenin diğer nüshalarına ne ölçüde taşındığı da önemlidir. Bu bağlamda Râşid Efendi'de sahh olarak yer alan aşağıdaki birkaç örneğin, Latîfî Tezkiresi'nin nüshalarından Kılıç Ali Paşa 780 ve Hâlet Efendi 342'de bulunup bulunmadıklarına dair veriler aşağıda tablo şeklinde sunulmuştur. ${ }^{2}$ Tablodan anlaşılacağı üzere Râşid Efendi'deki sahh kayıtları Hâlet Efendi nüshasıyla önemli ölçüde örtüşürken Kılıç Ali Paşa nüshasıyla ayrışmaktadır. Sadece Kılıç Ali Paşa örneği üzerinden konuşulacak olursa Râşid Efendi'deki sahh kayıtlarının tezkirenin bütün nüshalarınca benimsendiğini söylemek mümkün değildir:

\footnotetext{
${ }^{2}$ Aslında istatistiksel açıdan bir anlam ifade edebilmesi için sahh kayıtları tablosunun sayıca daha çok nüshayla yapılması gereklidir. Ancak burada üzerinde durmak istediğimiz konu, sahh kayıtları değil de bilgi/okuyucu notları olduğundan üç nüshadan oluşan mikro ölçekte bir mukayese ile yetinilmiştir. Râşid Efendi ile mukayese için Hâlet Efendi nüshasını tercih sebebimiz, Latîfî Tezkiresi'nin genişletilmiş versiyonu (sayılan) Hâlet Efendi nüshasıyla ilk versiyon kabul edilen Râşid Efendi nüshası arasında, derkenarlar noktasında, organik bir bağ olup olmadığını görebilmek içindir. Mukayesede kullandığımız Kılıç Ali Paşa nüshası ise Latîfî Tezkiresi'nin önemli nüshalarındandır. Bu nüsha, şair sayısı ve diğer nüshalarda bulunmayan bazı şairleri ihtiva etmesi nedeniyle Rıdvan Canım tarafından hazırlanan tezkirenin tenkitli neşrinde de yer almıştır. Neşir için bkz. (Canım, 2000). Diğer taraftan yaklaşık olarak tezkirenin ilk versiyonundan 62, genişletilmiş versiyonundan ise 33 yıl sonra istinsah edilmesine rağmen Râşid Efendi nüshasındaki sahh kayıtlarının birçoğunu bulundurmamak Kılıç Ali Paşa nüshasının tuhaf bir yönü olarak ortaya çıkmaktadır. Bu yüzden tabloda Râşid Efendi ile mukayese için Hâlet Efendi'nin yanı sıra Kılıç Ali Paşa nüshası da kullanılmıştır.
} 
Tablo-1: Sahh kayıtları

\begin{tabular}{|c|c|c|}
\hline Râşid Efendi 1160'taki sahh kaydı & Hâlet Efendi 342 (h. 983) & $\begin{array}{l}\text { Kılıç Ali Paşa } 780 \\
\text { (h. 1016) }\end{array}$ \\
\hline $\begin{array}{l}\text { 1) Ve cemî'-i menâkıb u me‘âsirden } \\
\text { belâgat u fesâhat evlâ vü efdal oldı. } \\
\text { Beyt: Şerefi nutkıladur insânun/ } \\
\text { Şeref-i nutk fesâhatdur lîk (Raşid } \\
\text { Efendi, yz. } 1160,4 \text { b) }\end{array}$ & $\begin{array}{l}\text { Ve cemî‘-i menâkıb u me'âsirden } \\
\text { fesâhat u belâgat evlâ vü efdal oldı. } \\
\text { Beyt: Şerefi nutkıladur insânun/ } \\
\text { Şeref-i nutk fesâhatdur bil (Hâlet } \\
\text { Efendi, yz. } 342,3 b \text { ) }\end{array}$ & YOK \\
\hline $\begin{array}{l}\text { 2) [mısra]': Tutdı cihânı zerk u riyâ } \\
\text { şi‘ri kim okur (Raşid Efendi, yz. } \\
1160,4 b)\end{array}$ & $\begin{array}{l}\text { misra': Tutdı cihânı zerk u riyâ şi'ri } \\
\text { kim okur (Hâlet Efendi, yz. 342, 3b) }\end{array}$ & YOK \\
\hline $\begin{array}{l}\text { 3) Beyt: İsterem bir gûşeyi kim ehl-i } \\
\text { âlem olmaya/ Ehl-i âlemden bana tâ } \\
\text { bir nefes gam olmaya (Raşid Efendi, } \\
\text { yz. 1160, 8a) }\end{array}$ & $\begin{array}{l}\text { Beyt: İsterem bir gûşeyi kim ehl-i } \\
\text { âlem olmaya/ Ehl-i âlemden bana tâ } \\
\text { bir nefes gam olmaya (Hâlet Efendi, } \\
\text { yz. } 342,6 a \text { ) }\end{array}$ & YOK \\
\hline $\begin{array}{l}\text { 4) Beyt: Gerekdür her kişiye adl ü } \\
\text { insâf/ Nitekim şâha himmet şâ'ire lâf } \\
\text { didikleri gibi (Raşid Efendi, yz. 1160, } \\
\text { 13a) }\end{array}$ & $\begin{array}{l}\text { Beyt: Gerekdür her kişiye adl ü } \\
\text { insâf/ Nitekim şâha himmet şấire lâf } \\
\text { didikleri gibi (Hâlet Efendi, yz. 342, } \\
\text { 9a) }\end{array}$ & YOK \\
\hline $\begin{array}{l}\text { 5) Ahsen-i vech üzre i'tirâzlarumı } \\
\text { def‘ ve ihtirâzlarumı ref' idüp (Raşid } \\
\text { Efendi, yz. 1160, 14a) }\end{array}$ & $\begin{array}{l}\text { Ahsen-i vech üzre i'tirâzlarumı def' } \\
\text { ve ihtirâzlarumı ref' idüp (Hâlet } \\
\text { Efendi, yz. } 342,9 b \text { ) }\end{array}$ & $\begin{array}{l}\text { Ahsen-i vech üzre } \\
\text { i'tirâzlarumı def‘ ve } \\
\text { ihtirâzlarumı ref‘ idüp } \\
\text { (Kılıç Ali Paşa, yz. 780, } \\
\text { 13a) }\end{array}$ \\
\hline $\begin{array}{l}\text { 6) Beyt: Bilürsin cihân bezmi bâkî } \\
\text { degül/ Giden gelmez ayruk mülâkî } \\
\text { degül (Raşid Efendi, yz. 1160, 14a) }\end{array}$ & $\begin{array}{l}\text { Beyt: Bilürsin cihân bezmi bâkî } \\
\text { degül/ Giden gelmez ayruk mülâkî } \\
\text { degül (Hâlet Efendi, yz. } 342,9 b)\end{array}$ & YOK \\
\hline
\end{tabular}

Râşid Efendi'deki sahh kayıtlarının ne zaman düşüldüğüne dair net bir bilgimiz olmamakla birlikte bunlar için birkaç ihtimal söz konusudur. İlk ihtimale göre sahh kayıtları Râşid Efendi nüshasının istinsah yılı olan 953/1546'da, ikinci ihtimale göreyse tezkireyi tamamlayıcı mahiyetteki bilgi/okuyucu notlarının da kaleme alındığı yıl olan 957/1550-51'de düşülmüş olabilir. Sahh kayıtlarının, bu iki ihtimal dışında, daha sonraki yıllara ait bir nüshadan da Râşid Efendi'ye taşınması muhtemeldir. Şayet sahh kayıtları 1546'da düşülmüşse Râşid Efendi nüshasının eksiklerini tamamlamak için kullanılan ve şu an için hakkında bilgi sahibi olmadığımız daha eski bir nüsha var demektir. Bu farazî nüshanın mukayesesi ile Râş̧id Efendi'nin eksikleri tamamlanmış olabilir. Şayet sahh kayıtları, okuyucu notlarının tutulduğu yıl olan 957/1550-51'e aitse bilgi notlarını tutan kişi ile sahh kaydını düşenin aynı kişiler olma ihtimali mevzu bahistir. ${ }^{3}$

${ }^{3}$ Kullanılan yazı tipi (hat) açısından sahh kayıtları ile okuyucu notlarının mukayesesi için krş. Resim-1 (sahh kaydı 


\section{Râşid Efendi'deki Okuyucu Notları ve Mahiyetleri}

Bu yazıda özellikle üzerinde durmak istediğimiz derkenarlar ise tezkiredeki bazı biyografik şahsiyetlere dair malumat sunan okuyucu/bilgi notlarıdır. Râşid Efendi nüshasındaki bu notlar, daha sonra verilecek örneklerden de görüleceği üzere, ne Latîfî Tezkiresi'nin genişletilmiş versiyonuna ne de devrin diğer tezkirelerine kaynaklık etmiş gibidir. Sahh kayıtlarıyla iç içe bulunan bu notların sonlarına çoğu zaman "ayn" harfine benzer bir işaret koyulurken bazen "mîm" harfi koyulmuş, bazen de hiçbir özel işaret kullanılmamıştır. Râşid Efendi'ye derkenar olarak kaydedilmiş bu notlar muhteva itibarıyla kimi zaman tezkiredeki şairlerin Latîfî tarafından zabtedilememiş şiir örneklerini sunarken kimi zaman da şairlere dair satır arası denebilecek bilgiler sunmaktadır. Notların bazılarında "Latîfî, Mevlânâ Latîfî ve müellif hazretleri" gibi ibarelerle doğrudan tezkire müellifine göndermeler yapılmaktadır. Latîfî Tezkiresi'nin yazma geleneğine dair yapılan bazı çalışmalarda ${ }^{4}$ Râşid Efendi nüshasındaki bu notların kime ait olduğu hususuna ilişkin dikkat çekici bir iddia gündeme getirilmiştir. Buna göre bunlar bizzât Latîfî́ye aittir ve tezkirenin zenginleştirilerek Sultan III. Murâd'a sunulan Hâlet Efendi 342 numarada kayıtlı son hâline kaynaklık etmiştir:

\section{"Râşid Efendi nüshasindaki notları Latîfì'nin tuttuğunu düşünmemizin sebebi yazma üzerinden alınan Riyâzîl-yi] Üsküb̂̂ hakkındaki notlar ile tezkirenin 1575 tarihinde ikinci defa yazılması sırasında Latîfî'nin eklediği bilinen Riyâzîl-yi] Üskübî hakkındaki bilginin hem üslup hem de içerik olarak benzer olmasıdır (Andrews \& Dalyan, 2019, s. 57)."}

$\mathrm{Bu}$ vurgudan anlaşıldığına göre tezkirenin bizzat müellif tarafından zenginleştirilmiş ikinci versiyonunda yer alan Riyâzî-yi Üskübî maddesi bilinen en eski nüsha olan Râşid Efendi nüshasındaki notlara dayanmaktadır. Zira yeni versiyon tezkire metnindeki bilgilerle Râşid Efendi nüshasındaki Riyâzî-yi Üskübî'ye dair söylenenler içerik ve üslup bakımından benzerdir. Râşid Efendi nüshasındaki notların Latîfî́ye ait olması, ilk versiyon tezkire metninin zenginleştirildiğinin kanıtı ya da genişletilmiş versiyonun bir tür müsveddesi hükmünde olduğundan önem kazanmaktadır. Fakat, eğer ki bu notlar Latîfî́ye değil de ismini bilmediğimiz farklı bir okuyucuya aitse durum nasıl bir hâl alacaktır? Söz gelimi Kemâl Paşazâde Ahmed Çelebi, Hızrî, Şems-i Dervîş, Fenâyî, İshâk, Basîrî, Riyâzî-yi Üskübî ve daha birçok şair hakkında Râşid Efendi nüshasına düşülen bu notlar Latîfî Tezkiresi'ne dâhil edilecek midir? Tezkirenin genişletilmiş versiyonunda yer alan biyografilerle Râşid Efendi nüshasının derkenarında kayıtlı olanlar muhteva açısından ortak mıdır? Bu ve benzeri sorulara cevap bulabilmek için Râşid Efendi nüshasındaki notlara daha yakından bakmak elzemdir.

\subsection{Notlar neden düşülmüştür?}

Tezkirenin Râşid Efendi nüshasındaki bu notlar arka kapak zahriyedeki ${ }^{5}$ kayda bakılacak olursa Latîfî Tezkiresi'nin bilinen en eski nüshası olan Râşid Efendi'den yaklaşık dört yıl sonra (h. 957) kaleme alınmıştır. Bu kayıtta Râşid Efendi nüshasındaki okuyucu notlarının kim tarafından ve niçin tutulduğu noktasında net bir bilgi bulunmasa da en azından bunlara dair ipuçları mevcuttur. Arka kapak zahriyede Latîfî ve tezkiresine dair not şu şekildedir:

\footnotetext{
${ }^{4}$ Bu bağlamdaki çalışmalardan bazıları için bkz. (Andrews \& Dalyan, 2019), (Dalyan, 2020), (Andrews, 2015), (Andrews, 1996), (Andrews, 1970).

${ }^{5}$ Makalenin çeşitli yerlerinde geçen "arka kapak zahriye" ibaresi ön kapak zahriyeye muadil olarak kullanılmış olup bu ibare ile eserin bitiminden hemen sonra yer alan yaprak ile arka kapak içi kastedilmiștir.
} 


\begin{abstract}
"Bu kitâb-ı belâgat-me'âb ve fesâhat-iyâb selâtîn-i âl-i 'Osmândan Sultân Murâd Han zamânından pâdişâh-ı cihân Süleymân-ı zamân devrinde hicret-i nebeviyyenün tokuz yüz elli üç senesine gelince şu 'arâ-yı kirâm ve nuzemâ-yı 'izâmdan üç yüz 'aded şấ'ir-i fâzıl ve nâzım-ı kâmilün me'âsir ü menâkıbda ve makâdır u merâtibde tebyîn ü beyân ve her birinün ism ü resmin i 'lâm ve kemiyyet ü keyfiyyet ve isti 'dâd $u$ istitâ'atın i 'lânda tastîr ü tahrîr olınmışdur. Hakkâ ki bir ravzadur ki ezhâr-ı gĥu-â-gĥn ve eşcâr-ı bukalemûn-ı nüzhet-füzĥn-ı ferhat-nümûn ile mâl-â-mâl u meşhûndur. Ammâ bu kadar vardur ki şu'arâ-yı sihr-âmîzden ba'z-ı kâmillerün ism-i şerîfleri bu mecmû'a-yı letâ'ife ve bu sefine-yi ma ârife derc olmamagın kitâb-ı merkûm hedef-i hadeng-i ta'n vâki 'olmışdur. Ve bu altmış bir nefer kimse ki şu'arâ-yı zamânun muhtâr $u$ mümtâzlarından ve her birinün niçe gazel ü kasîdeleri ve niçe rubâ'î vü kut 'aları vardur. Ve niçesi semâ'a kâbil-i güftâr ve pesende lâyık-ı eş 'ârdur. Dürer-bâr u gevher-nisâra kâdirler iken hâric-i kitâb olmagin bir 'ârif-i 'avârif-nisâb ki envâ'-ı ma 'ârifile mevsûf u ma'rûf ve esnâf-ı fezâ'ilile me'nûs u me'lûfdur cem 'eylemişdür ki hakîr-i kesîrü't-taksîr dahı burada ketb itdüm. Fîsenetin seb 'a ve hamsîn ve tis 'a-mi'e 957 (Râşid Efendi, yz. 1160, 165b)."
\end{abstract}

Râşid Efendi nüshasının ana metninden farklı bir hatla kaleme alınan bu notta, Sultan II. Murad devrinden başlamak üzere Kanuni Sultan Süleyman devrinin hicrî 953'üne kadarki dönemine değin, Latîfî̀nin, tezkiresine üç yüz şairi aldığı belirtilmiş; ancak bazı şöhretli şairleri göz ardı ettiği için o günlerde çeşitli eleştirilere maruz kaldığı vurgulanmıştır. Zahriyedeki bu notu, Latîfî Tezkiresi'ndeki bu eksiğin kendi döneminde büyük bir infiale neden olduğu ve bunu telafi için entelektüel arenadan biri(leri) tarafından çeşitli şair listeleri oluşturulduğu şeklinde anlamak mümkündür.

Ayrıca arka kapak zahriyedeki bu kayıttan Râşid Efendi nüshasındaki bilgi/okuyucu notlarını tutan ile bunları derkenara işleyen(ler)in farklı kişiler olduğu sonucu da çıkmaktadır. Metnin son satırında geçen: "Bir 'ârif-i 'avârif-nisâb [...] cem ' eylemişdür ki hakîr-i kesîrü't-taksîr dahı burada ketb itdüm." ifadesi bu iddiamızı destekler mahiyettedir. Şu durumda kim olduğu hususunda hiçbir bilgimiz olmayan "bir ârif-i avârif-nisâb" tarafından Latîfî Tezkiresi'nin ilk versiyonundaki eksik ve hatalar tespit edilmiş ve yine kim olduğu hususunda herhangi bir kanaate sahip olmadığımız biri tarafından, tespit edilen bu eksiklikler bilgi/okuyucu notları biçiminde Râşid Efendi nüshasına derkenar olarak işlenmiştir. Şayet notların müellif/musannif ve yazıcısının farklı kişiler olduğuna dair böyle bir kayıt olmasaydı, Râşid Efendi nüshasının ön kapak zahriyesine düşülen hicrî 957 tarihli temellük kaydından -ki muhtemelen bilgi/okuyucu notlarını derkenarlara yazan bu kişidirmüellife dair bilgi edinmek mümkün olabilecekti. Ancak şu an için bu durum mümkün gözükmemektedir.

\title{
1.2. Notların Latîfî'ye aidiyeti meselesi
}

Metinde "bir ârif-i avârif-nisâb" olarak nitelenen notların sahibinin Latîfî olma ihtimali, sadece arka kapak zahriyedeki birkaç satırla geçiştirilecek türden bir iddia değildir. O yüzden bu başlık altında muhteva ve mahiyetlerden hareketle notların Latîfí'ye aidiyeti meselesi sorgulanmaya çalışılmıştır. Bu bağlamda Râşid Efendi nüshasındaki Şems-i Dervîş (Şemsî-yi Dervîş/ Dervîş Şemsî), Kemâl Paşazâde Ahmed Çelebi, Hızrî, Fenâyî ve Riyâzî-yi Üskübî gibi şairlere dair tutulan notlar örnek olması bakımından hem Latîfî Tezkiresi hem de dönemin diğer tezkireleri çerçevesinde incelenmiştir. Tezkireci Latîfî'nin Şems-i Dervîş hakkında söyledikleri ve Râşid Efendi'deki notu düşenin buna itirazları aşağıda sunulmuştur:

SEFAD, 2020; (44): 161-180 
Râşid Efendi nüshasının tezkire kısmında "Şems-i Dervîş"e dair verilen bilgi:

"Şems-i Dervîş rahmetullâhi 'aleyh Seferihisârdan ışık Şems dimegile ma'rûfdur. Kitâb-ı Deh Murgun mü'ellifi ve dahı niçe fennün sâhib-tasnîfidür. Kitâb-ı merkûmı mezbûr merhûm Sultân Selîme sundukda Selîm Han haylî ihsân u istihsân itmişdür (Râşid Efendi, yz. 1160, 94b-95a)."

Râşid Efendi nüshasındaki okuyucu notunda "Şems-i Dervîşs"e dair verilen bilgi:

"Mü'ellif hazretleri Mevlânâ Latîfi burada sehv itmişlerdür. Zîrâ nakl itdükleri ebyât-ı pür-nikâtı müşsemil ve beyne'l-enâm Deh Murg- $\iota$ Şemsî dimegile ma 'rûf u meşhûr olan kitâb-ı müstetâbun mü'ellif ü musannifi olan "Mevlânâ Şems bu 'asr şu'arâsindandur. Kitâb-ı merkûmı pâdşâhumuz Sultân Süleymân Han Hazretlerinün nâm-ı hümâyûnlarlyıla mu'anven idüp Engürüs ve

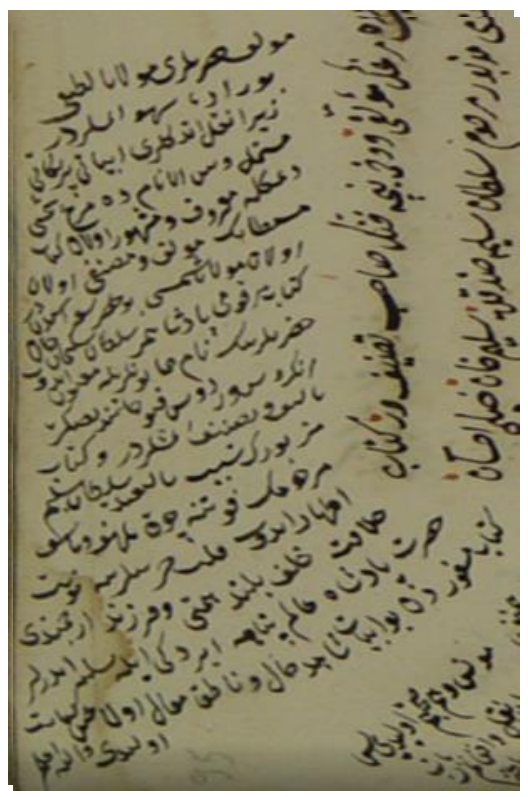

Resim- 3: Râçid Ifendi nüshasundaki Şems-i Deviş'́ dair bilgi/okuyucu notu Rodos fütûhâtından sonra te'liff ü tasnîf itmişlerdür. Ve kitâb-ı mezbûrun sebeb-i te'lîfinde Sultân Selîm-i merhûmun fevtine çok tehellüf ü te'essüf izhâr idüp kalb-i hazînlerine nevbet-i hilâfet halef-i bülend-himmeti ve ferzend-i ercmendi Hazret-i Pâdşâh1 'âlem-penâha irdügi ile tesliye iderler (Râşid Efendi, yz. 1160, 95a)".

Râşid Efendi nüshasının tezkire kısmındaki Şems-i Dervîş maddesi, Râşid Efendi nüshasındaki derkenar notuyla bir arada okunduğunda ışık Şems diye anılan Şems-i Dervîş'in Kanuni Sultan Süleyman dönemi şairlerinden olduğu ve ünlü kitabı Deh Murg'u Sultan Selîm'e değil, Sultan Süleyman'a sunduğu anlaşılmaktadır. Tezkirenin ikinci versiyonunun son hali kabul edilen Hâlet Efendi 342'de kayıtlı yazma ile Râşid Efendi'deki okuyucu notunu mukayese ettiğimizde ilginç bir durumla karşılaşılmaktadır. Öyle ki bizzat Latîfî tarafından tutulup tezkirenin genişletilmiş haline kaynaklık ettiği iddia edilen bu notlar, tezkirenin ikinci versiyonunda yer almamakta ve Şems-i Dervîş/ Şemsî-yi Dervîş tıpkı tezkirenin ilk versiyonu sayılan Râşid Efendi nüshasında olduğu gibi Sultan Selim dönemi şairlerinden sayılıp Deh Murg adlı eserini de Sultan Selim'e sunmuş olarak gösterilmektedir (Hâlet Efendi, yz. 342, 87a). Âşık Çelebi ve Kınâlızâde Hasan Çelebi tezkirelerinde de Latîfî Tezkiresi'ndeki rivayet tekrarlanmış ve Râşid Efendi nüshasındaki notta vurgulanan, Deh Murg'un Engürüs ve Rodos'un fethini müteâkip Sultan Süleyman'a sunulduğu iddiası dikkate alınmamıştır. Şems-i Dervîş'e dair malumatın devrin diğer tezkireleriyle mukayesesi için bkz. (Kılıç, 2010, s. 1435-36; Kutluk, 1989, s. 521; Sungurhan, 2017, s. 474-75). Şems-i Dervîş hakkındaki bu not ilerleyen satırlarda Râşid Efendi'deki okuyucu notlarının güvenilirliği bağlamında yeniden ele alınacaktır. 
Râşid Efendi nüshasında Latîfî Tezkiresi'ne dair düşülen notlardan biri de Kemâl Paşazâde Ahmed Çelebi ile ilgilidir. Bu nota göre Latîfî́nin, Ahmed Çelebi'nin doğduğu yere dair aktardığı bilgi hatalı olduğundan bu hususta ona itimat edilmemelidir. Aşağıdaki metinlerde de görüleceği üzere Latîfî Tezkiresi'nin ilk şekli kabul edilen Râşid Efendi nüshasına göre Ahmed Çelebi'nin doğum yeri Tokat, yetiştiği yer Edirne'dir. $\mathrm{Bu}$ bilgi tezkirenin ikinci versiyonu sayılan Hâlet Efendi nüshasında da aynen tekrarlanmakta ve ekser-i nâssın bu malûmâttan haberdar olmadığı vurgulanmaktadır (Râşid Efendi, yz. 1160, 42a, Hâlet Efendi, yz. 342, 31b). [Latîfî Tezkiresi'nin Kılıç Ali Paşa nüshasında ise Ahmed Çelebi'nin doğum yeri Amasya, büyüdüğü yer Edirne olarak kaydedilmiştir (K1lıç Ali Paşa, yz. 780, 35b).] Râşid Efendi nüshasının derkenarındaki notta ise tüm bunlardan farklı olarak Ahmed Çelebi'nin doğum yerinin Edirne olduğu belirtilmiştir. Notu düşen kişi bu iddiasını Ahmed Çelebi'nin talebelerine dayandırmaktadır. Buna göre talebelerin arasında

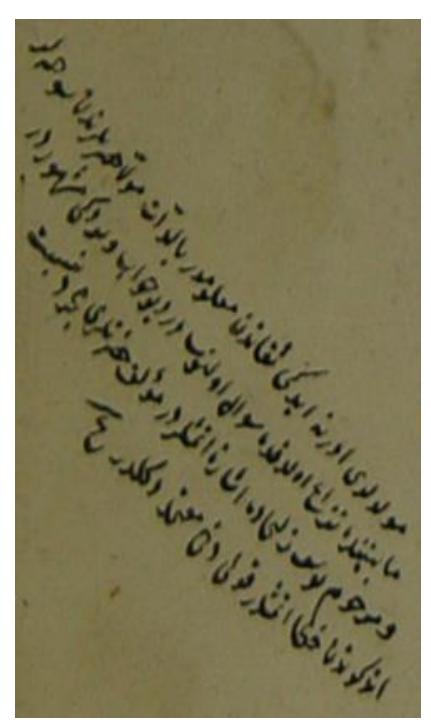

Resim-4: Râşid Efendi'deki Kemâl Paşazâde Ahmed Çelebi'ye dair bilgi/okuyucu notu Ahmed Çelebi'nin doğum yerine ilişkin bir iddialaşma olunca mesele doğrudan hocaları Molla Ahmed Çelebi'ye götürülmüş ve Ahmed Çelebi'nin doğum yerinin Edirne olduğu bizzat kendisinden öğrenilmiştir. Tezkirenin genişletilmiş versiyonunda Râşid Efendi nüshasındaki bu "not"a itibar edilmediği çok açıktır. Ayrıca asrın diğer tezkirecileri de gerek Râşid Efendi nüshasındaki nota gerekse Latîfî́nin her iki versiyonunda tekrarlanan bilgiye tezkirelerinde yer vermemiştir:

Kemâl Paşazâde Ahmed Çelebi'ye dair tezkirenin ilk versiyonu Râşid Efendi'deki bilgi:

"Kemâl Paşazâde Süleymân Çelebinün oghldur. Ve mevlidleri Tokatda vâki ' olup neşv ü nemâları Edirnede olmışdur (Râşid Efendi, yz. 1160, 42a)."

Kemâl Paşazâde Ahmed Çelebi'ye dair tezkirenin genişletilmiş versiyonu Hâlet Efendi'deki bilgi:

"Kemâl Paşazâde Süleymân Çelebinün mahdûm-zâdesidür. Livâ-yı Tokatda ze'âmete mutasarrnf iken dünyâya gelmişlerdür. A' 'nî mevlid-i mübârekleri Tokatda vâki' olup neş ü nemâlar Edirnede olmışdur. Ekser-i nâs bundan gâfil ve gafletle câhildür (Hâlet Efendi, yz. 342, 31b)"

Kemâl Paşazâde Ahmed Çelebi ile ilgili Râşid Efendi nüshasının derkenarındaki okuyucu notu:

"Mevlidleri Edirne idügi sikâtdan ma lûmdur. Bizzât Mollâ hazretlerinden sûhteler mâbeyninde nizâ' oldukda su'âl olınup [E]dir[ne] diyü cevâb virdügi meşhûrdur. Ve merhûm Yûsuf u Züleyhâda işâret itmişlerdür. Mü'ellif hazretleri mücerred nisbet itdügünden hatâ itmişdür. Kavli dahı mu'temed degüldür (Râşid Efendi, yz. 1160, 42a)."

Râşid Efendi nüshasındaki notlardan biri de Latîfî'de Hızrî diye anılan Hızrî-yi Yenihisârî hakkındadır. Râşid Efendi'deki bu notların Latîfî'deki "Hızrî" biyografisine katkısı yeni şiir örnekleri vermesi dışında sadece "nisbe" noktasındadır. Latîfî'nin gerek ilk gerekse ikinci versiyonunda "Yenihisâr" ile ilgili bir kayıt yokken Râşid Efendi'deki notta Hızrî, 
Yenihisârî nisbesiyle anılmış ve arka kapak zahriyede tezkirede olması gereken şairler sıralanırken [sanki Latîfí'de böyle bir şair hiç yokmuş gibi] Hızrî-yi Yenihisârî ismi zikredilmiştir. Âşık Çelebi, Ahdî ve Kınalızâde Hasan Çelebi tezkirelerinde Hizrî'nin Yenihisar'dan olduğu vurgulanmak suretiyle Râşid Efendi'deki not doğrulanmaktadır. Bunun dışında Hızrî́nin danişmendliği, tasavvufa meyli, Şam'da yeniçeri olarak yazılması, divane meşrep hâli, eski ve yenilerden birçok şairin divanlarını tetebbu edişi Latîfî dâhil olmak üzere adı geçen bütün tezkirelerde (Kılıç, 2010, s. 1532-34; Kutluk, 1989, s. 344; Sungurhan, 2017, s. 335; Solmaz, 2005, s. 290-91) dile getirilmektedir. Hatta bu noktalarda Râşid Efendi'deki notta Hizrî́ye dair verilen malumat ile diğer tezkirelerin verdiği mukayese edilecek olursa nottaki bilgilerin çok daha eksik ve anlaşılmaz olduğu görülecektir. Râşid Efendi'de Hızrî-yi Yenihisârî̀ye dair tutulan notun bir kısmı şu şekildedir:

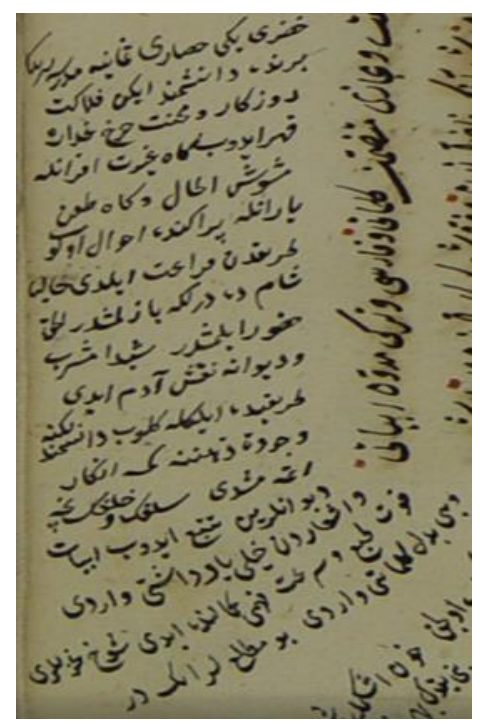

Resim-5: Hızrî'ye dair Râşid Efendi'deki okuyucu notu

"Hizrî-yi Yenihisârî Semâniye medreselerinden birinde dânişmend iken felâket-i rûzgâr ve mihnet-i çarh-ı gaddâra kahr idüp gâh gayret-i akrânıla müşevveşü'l-hâl ve gâh ta 'n-ı yârânıla perâkende-ahvâl olup tarîkdan ferâgat eyledi. Hâliyâ Şâmda dirlüge yazılmışdur. El-hak huzûr eylemişdür. Şeydâ meşreb ve dîvâne-nakş âdem idi. Tarîkda eylükle? gelüp dânişmendlügine ve cevdet-i zihnine kimse inkâr itmemişdi. Selefün ve halefün niçe dîvânların tetebbu' idüp ebyât u eş 'ârdan haylî yâd-dâştı vardı. Kuvvet-i tab' ve sür 'at-i fehmi kemâlinde idi. Şûh gazelleri ve bî-bedel kelimâtı vardı. Bu matla lar anundur (Râşid Efendi, yz. 1160, 68a)."

Farklı birçok şairde olduğu gibi Hızrî-yi Yenihisârî'ye dair Râşid Efendi'deki bu notlarda Latîfî ve diğer tezkirelerde zikredilmeyen şiir örneklerinin olması notların ayrıcalıklı tarafıdır. Notlarda Hızrî adına kayıtlı altı adet beyit, altı beyitlik bir gazel ve şairin bir murabbainın matlaı ne Latîfî ne de yüzyılın diğer tezkirelerinde mevcuttur. Bu yönüyle Râşid Efendi'deki okuyucu/bilgi notları oldukça özgün ve kıymetlidir.

Râşid Efendi nüshasındaki okuyucu notlarının mahiyet olarak Latîfî́nin yanlışlarını düzeltme fonksiyonu yanında Latîfî'nin, tezkiresine almadığı bazı şairleri vurgulama gibi bir yönü daha vardır. Bu bağlamda Râşid Efendi'nin arka kapak zahriyesinde uzun bir şair listesi göze çarpmaktadır. Notların düzenleyicisine göre tezkirenin kâmil bir hâle bürünebilmesi için bu şairlerin de tezkireye dâhil

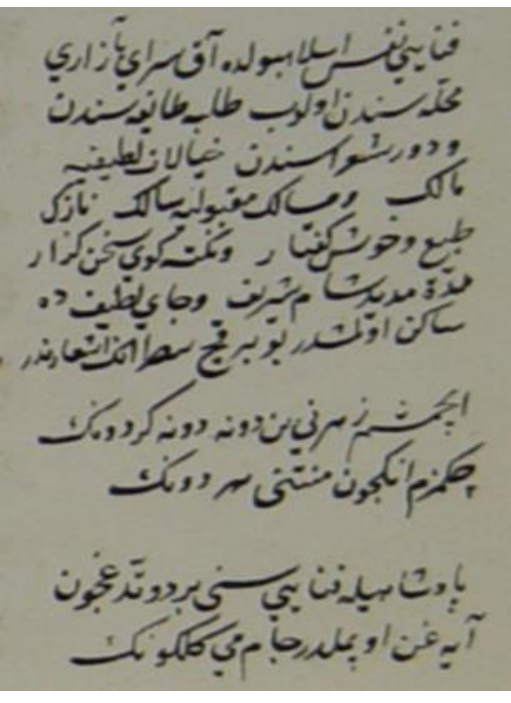

Resim-6: Fenâyî'ye dair Râşid Efendi'deki okuyucu notu edilmesi elzemdir. Tezkireye eklenmesi gerekli şairler için Râşid Efendi'deki notlarda ismi zikredilen "Fenâyî" ve "Riyâzî-yi Üskübî" namıla iki şair burada örnek olarak alınacaktır. Bunlardan Riyâzî-yi Üskübî Râşid Efendi nüshasının arka kapak zahriyesinde "Riyâzî-yi Mülâzım" olarak verilmiştir. "Fenâyî" mahlaslı şair ise zahriyede hiç zikredilmemiştir. Yani 
notların sahibi, tezkireye eklenmesi gerekenler adı altında yer vermediği bir şaire burada yer vermiştir. Fenâyî'ye dair tezkiredeki not şöyledir:

"Fenâyî: Nefs-i İslâmbol'da Aksarây Bâzârn mahallesinden olup talebe tâ'ifesinden ve devr şu 'arâsından hayâlât-ı latîfeye mâlik ve mesâlik-i makbûleye sâlik nâzik tab' u hoş güftâr ve nükte-gûy suhan-güzâr müddet-i medîd Şâm-l şerîf ve cây-ı latîfde sâkin olmışdur. Bu birkaç satr anun eş 'ârın[dan]dur: İ̧̧mişem zehrini ben döne döne gerdûnun/ Çekmezem anunıçün minnetini her dûnun/ Pâdşâhıyla Fenâyî seni bir dutdugı̨̧ün/ Ayagın öpmelidür câm-ı mey-i gülgûnun (Râşid Efendi, yz. 1160, 117b)."

Latîfî Tezkiresi'nin gerek ilk versiyonu sayılan Râşid Efendi 1160, gerekse genişletilmiş versiyonu kabul edilen Hâlet Efendi 342'de Fenâyî maddesi yoktur. Bununla birlikte "Fenâyı̂" isminin dönemin bazı tezkirelerinde geçtiği vâkidir. Ancak tezkirelerin bahsettiği Fenâyî ile Râşid Efendi nüshasındaki okuyucu notunda bahsedilen Fenâyî'nin ayn kişiler olduğu hususu net değildir. Ahdî'nin Gülşen-i Şuarâ'sında doğum yeri Manisa olup İstanbul'da yetiştiği belirtilen Fenâyî adlı bir şairden bahsedilmektedir (Solmaz, 2005, s. 479-80). Ahdî'deki Fenâyî ile Râşid Efendi'ye derkenar olarak kaydedilen Fenâyî arasında "İstanbul" da yaşamaları dışında ortak bir şey bulunmayıp şairin talebe tâifesinden olduğu, İstanbul'un Aksaray Pazarı mahallesinde yaşadığı ve uzun müddet Şam'da ikâmet ettiğine dair hiçbir kayıt yoktur. Âşık Çelebi ve Kınalızâde Hasan Çelebi tezkirelerinde yer almayan Fenâyî'ye, Sehî Bey ve Gelibolulu Âli'de rastlanılmaktadır. Sehî Bey'de şaire dair rivayet birkaç satırdan ibaret olup onun Sultân II. Mehmed devrinin şairlerinden olduğu, birçok gazeli bulunup divan sahibi olduğu belirtilmektedir. Bu ifadelerden sonra Heşt Bihişt, Fenâyî'nin üç beytini örnek olarak sunmuştur (İpekten, Kut, İsen, Atay \& Karabey 2017, s. 90). Fenâyî, Gelibolulu Âlî Tezkiresi'nde ise müstakil bir madde olarak değil "Asskî" maddesinde yer almaktadır; kendisi gibi II. Mehmed dönemi şairlerinden olan Aşkî ve Sa 'dî ile muasırdır. Gelibolulu Âlî ve Sehî’de Fenâyî isminin geçtiği yer, bu iki tezkirede Aşkî adına kayıtlı olan:

\section{'Aşkî yüz yir Sa'dî otuz bu Fenâyînün dahı}

Ayda otuz güni vardur tonlug u tîmarda

şeklindeki beyittir (İsen, 1994, s. 141; İpekten vd., 2017, s. 90). Muhtemelen Sehî ve Gelibolulu Âlî̀'de geçen Fenâyî aynı kişidir. Ancak bu kişi ile Râşid Efendi'deki notlarda geçen Fenâyî'nin aynı kişiler olup olmadığına dair kesin bir şey söylemek zordur.

Tezkirenin ilk versiyonunda yer almadığı için derkenar olarak kaydedilen isimlerden biri de Riyâzî-yi Üskübî ya da arka kapak zahriyedeki kayıtla söylenecek olursa Riyâzî-yi Mülâzım'dır. Riyâzî-yi Üskübî, Fenâyî örneğinde olduğunun aksine, tezkirenin genişletilmiş hali kabul edilen Hâlet Efendi nüshasına alınmıştır. Yukarıda da vurgulandığı üzere Râşid Efendi nüshasındaki notların tezkirenin yeni versiyonuna kaynaklık edip bunların Latîfî’ye ait olduğu şeklindeki iddianın temelinde de Riyâzî-yi Üskübî yer almaktadır. Bu yüzden Râşid Efendi'deki derkenar ile Hâlet Efendi'deki Riyâzî-yi Üskübî’yi mukayese etmek

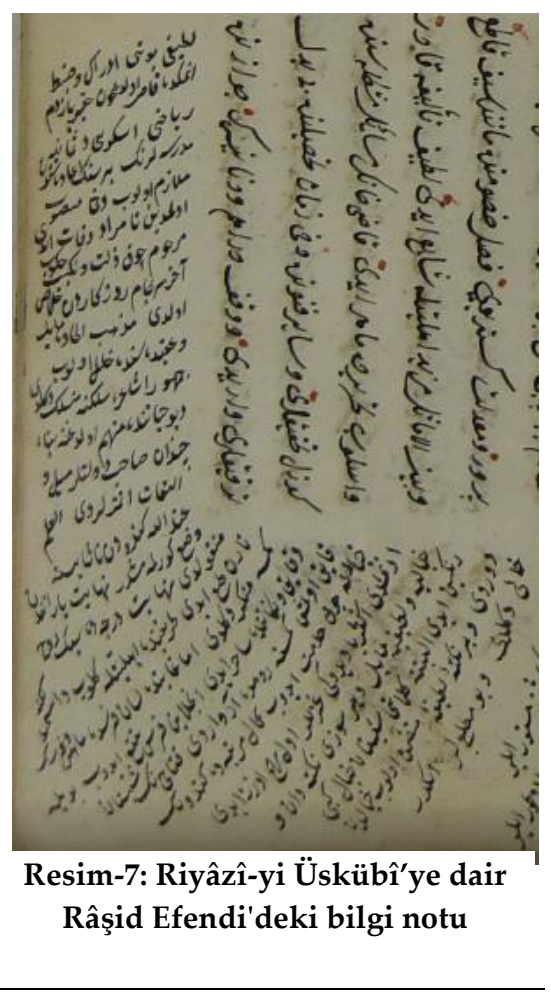

SEFAD, 2020; (44): 161-180 
gereklidir. Râşid Efendi nüshasındaki notta Riyâzî-yi Üsküb̂̂’ye dair malumat şöyledir: "Latîfî bun idrâk u zabt itmekde kâsır oldugıçün hakîr yazdum. Riyâzî, Üskübîd[ür]. Semâniyye Medreselerinün birinün i âdesinden mülâzım olup dahı ma[n]sû[b] olmadın nâ-murâd vefât itdi. Merhûm çok zillet ü nekbet çeküp âhir ser-[en] câm-ı rûzgârdan halâs oldr. Mezheb-i ilhâda mâ'il ve 'akîdesinde halel olup cumhûren şâ'ir silkine münselik degüldi diyü hayâtında müttehem oldugına binâ'en çendân sâhib-devletler meyl ü iltifât itmezlerdi. El-'ilmu 'indallâh kendüden nâ-şâyeste vaz' görilmemişdür. Nihâyet yârânından menkûldi. Nihâyet derecede sebük-rûh [ve] nârin ta[b]' idi. Tarîkında ehliyyetle gelüp dânişmendlügine kimse münkir degüldi. Ammâ gâyetde lisân-ı Fürsde mâhir ve Fürsün dakâyık u nikâtında sâhir idi. Ançılayın Fürs tetebbu 'idüp böyle fâ'ik olmış kimesne Rûm'da az vardı. Fettâhı̂'nün Şebistân-ı Hayâl'ine çok hıdmet idüp kemâl mertebede kendünün idinmişdi. Ekseriyâ didügi gazeller ol [n]ehc üzre idi. Hayâliyye ve latîfeye mâ'il ve her sözi nüktedân u rengîn idi. Elbette kelimâtı şebistân-ı hayâl gibi dürûy ve bir nükte-yi latîfe-yi mutazammın olup hayâlden hâlî degüldi (Râşid Efendi, yz. 1160, 80b)."

Tezkirenin genişletilmiş versiyonu sayılan Hâlet Efendi 342'de Riyâzî-yi Üskübî’ye dair aktarılanlar ise şu şekildedir:

"Riyâzî-yi Üskübî rahmetullâhi 'aleyh: Talebe tâ'ifesinden Hayâlî mu'âstrlarındandur. Semâniye i’âdesinden mülâzım ve mülâzemetde müdâvim iken vefât itdi. Ol ehvâ-yl ârzûdayken cihân-ı gam-âbâddan nâ-kâm u nâ-murâd gitdi. Zamân-ı kazâsı ve tab 'ınun muktezâsı gelmiş idi. Tedrîsden geçüp kazâya rzzâ virmiş iken me'mûl u maksûdına irmedi ve ümmîd ü recâsı yüzin görmedi. Emâsil ü akrân beyninde haylî imtiyâz u iştihâr bulmış makbûl dânişmend ve semt-i siyâk-ı suhanda bî-mânend idi. Açuk mezheb ve lâubâlî meşreb kimesne idi. Hîn-i musâhabetde ekser-i kelimâtında kasd-ı tecnîs ü îhâm ve ta 'biye-yi zarâfet-i kelâm sanâyi'-i şebistâna müte'allik her suhanda bir zarâfet ve her 'ibâretde envâ'- - nikâtdan bir nükte kinâyet iderdi. Semt-i siyâkat-i suhanda mezbûrun hâliyâ mukallid ü peyrevi vâfirdür. Ammâ ol tarzda anun emsâli bir kâbil-i şân fîzemâninâ gâyetde ekall ü nâdirdür. Li-mü'ellifihî: Ey mukallid dâd-ı Hakdur her hüner bir kâmilel Yohsa taklîd ile nâkıs kâmil olmaz şöyle bil. Ve zarâfet 'add idüp ilhâd u ibâhata müte 'allik ba'z-ı kelimât ihtiyâr u irtikâb itdügi eclden ekser-i nâs mezhebinde viü'at ve ba'zular ol sûret-i vüs'ati mahz-ı zarâfet 'add itdi. "حمل المؤمن على الصلاح' fehvâsınca tebâdür iden budur ki müşârün ileyhün ekser-i mu 'âmele ve musâhabeti nevhâste vü nev-heves civânlar ile olmagmn "مجالسة الاحداث مفسدة الدين" muktezâsmca anlarun meyl ü hevâsına kemâl-i ittibâ' u inkıyâd itmegile dimâg-ı zühd ü sâlâh u felâhın fenâ vü fesâda ve hırmen-i fevz ü felâhın ilhâd u ifsâda virmiş idi. Bedî' ü ba î̀d olmaya ki ihvân-ı dîn katında ol gûne ihvân u yârân ihrâb u ebâlise ve şeyâtîn-i insden 'add olınur (Hâlet Efendi, yz. 342, 71a-71b)."

Yukarıdaki metinlerin değerlendirmesine geçmeden en başta şunun altını çizmek gereklidir ki Riyâzî-yi Üskübî'ye dair notun ilk satırındaki: "Latîfî bunı idrâk u zabt itmekde kâsır oldugıçün hakîr yazdum." şeklindeki ibare, Latîfî'nin kendisine böyle hakaretvârî bir üslûpla hitap etmesi mantıklı olmadığından, Râşid Efendi'deki okuyucu/bilgi notlarının bizzat tezkirenin müellifi Latîfî tarafından tutulduğu ihtimalini epeyce zayıflatmaktadır.

Râşid Efendi'deki not ve Hâlet Efendi'deki kayıtta ortak olanlardan biri Riyâzî́nin Semâniye i'âdesinden mülâzım olup bir vazifeye atanamadan vefat etmesi ve mizâcen "rafz u ilhâd"a mâil olmasıdır. Hâlet Efendi'de Riyâzî'nin mülhid damgası yemesinin gerekçesi 
zarafet kasdıyla bazı sözler sarfetmesi ve nev-heves civânlar (şehir oğlanları) ile gezip tozması gösterilirken Râşid Efendi'deki notlarda Riyâzî'nin zındıklığı hususunda kendisinden o minvalde bir tavır görülmeyip şairin etrafındaki bazı kişilerin ona dair böyle bir nakilde bulundukları şeklinde bir rivayet söz konusudur. Râşid Efendi'deki notlarda Riyâzî'nin zendeka ve ilhâd ithamı nedeniyle dönemin önde gelenleri (sâhib-devletler) tarafından tecrit edildiği, hatta şâirler halkasına dahi dâhil edilmediği kayıtlıdır. Notlar bu yönüyle özgündür. Gerek Hâlet Efendi nüshasında gerekse Râşid Efendi'deki notta Riyâzî'nin üslûben şebistân-ı hayâl denen kelime oyunlarına düşkünlüğü vurgulanmıştır. Ancak Râşid Efendi'de belirtilen, Riyâzî'nin Farsça'daki üstün kabiliyeti ve Fettâhî'nin Şebistân-1 Hayâl'i üzerinde üslûben onu kendisi için bir meleke haline getirecek kadar çalıştı̆̆ı şeklindeki malumat Hâlet Efendi nüshasında yoktur. Ayrıca Riyâzî'nin dânişmendliği, ilhâda meyilli yapısı ve laf oyunlarını seven mizacı Âşık Çelebi, Kınalızâde Hasan Çelebi, Ahdî ve Gelibolulu Âlî̀de parça parça tekrarlanmaktadır. Râşid Efendi nüshasındaki notlarda Riyâzî-yi Üskübî adına kaydedilen aşağıdaki beyitlerin Latîfî́nin zenginleştirilmiş versiyonu kabul edilen Hâlet Efendi nüshası ve devrin diğer tezkirelerinde bulunup bulunmadıkları hususu aşağıdaki tabloda gösterilmiştir:

Tablo-2: Râşid Efendi'deki notlarda bulunan Riyâzî'ye ait beyitlerin Latîfî neşirleri ve dönemin diğer tezkireleriyle mukayesesi

\begin{tabular}{|c|c|c|c|c|c|c|c|c|}
\hline $\begin{array}{l}\text { Râşid Efendi'deki derkenarlarda } \\
\text { Riyâzîlyi Üskübî adına kayıtlı } \\
\text { beyitler. } \\
\qquad \text { (vr. 80b) }\end{array}$ & $\begin{array}{l}\text { Latîfi } \\
\text { Ahmed } \\
\text { Cevdet } \\
\text { baskısı }\end{array}$ & $\begin{array}{l}\text { Latîfi } \\
\text { Hâlet } \\
\text { Efendi } \\
342\end{array}$ & $\begin{array}{l}\text { Latîfi } \\
\text { Canım } \\
\text { Neşri }\end{array}$ & $\begin{array}{l}\text { Latîfî } \\
\text { İsen } \\
\text { Neşri }\end{array}$ & $\begin{array}{l}\text { Aşık } \\
\text { Çelebi } \\
\text { Tez. }\end{array}$ & $\begin{array}{l}\text { Hasan } \\
\text { Çelebi } \\
\text { Tez. }\end{array}$ & $\begin{array}{c}\text { Ahdî } \\
\text { Tez. }\end{array}$ & $\begin{array}{c}\hat{A} l \hat{\imath} \\
\text { Tez. }\end{array}$ \\
\hline $\begin{array}{l}\text { Her kaçan zülfi benâgûşını } \\
\text { mestûr eyler/ Güpegündüz } \\
\text { gözüme â̂lemi deycûr eyler }\end{array}$ & Var & Var & Var & Var & Yok & Yok & Yok & Yok \\
\hline $\begin{array}{l}\text { Şûr u gavgâya virdiler dehri } \\
\text { Sürmelidür bu ala gözlüleri }\end{array}$ & Yok & Yok & Yok & Yok & Yok & Yok & Yok & Yok \\
\hline $\begin{array}{l}\text { Arûs-1 nev dirilme ey felek zâl-i } \\
\text { kühensin sen/ Niçe dâmâda } \\
\text { kendün râm kılmış pîrezensin } \\
\text { sen }\end{array}$ & Yok & Yok & Yok & Yok & Var & Var & Var & Yok \\
\hline $\begin{array}{l}\text { O mâh sûreti bir gün göreydük } \\
\text { ey Mânî/ Yolında eyleridük } \\
\text { harc-1 nakd-1 îmânı/// Rakîb-i } \\
\text { dîve ider iltifât bizden pek/ } \\
\text { Ferâgat eyle dilâ sevmeden } \\
\text { Süleymânı }\end{array}$ & Yok & Yok & Yok & Yok & Yok & Yok & Yok & Yok \\
\hline
\end{tabular}

Tablodan da görüleceği üzere Râşid Efendi'deki notlarda yer alan beyitler bütün olarak neredeyse hiçbir tezkirede bulunmamaktadır. Şu durumda Râşid Efendi'deki birçok derkenarda olduğu gibi Riyâzî-yi Üskübî maddesindeki kayıtların da ne Latîfî́nin genişletilmiş versiyonuna ne de dönemin diğer tezkirelerine kaynaklık ettiğini söyleyebilmek mümkündür. Tezkirenin tenkitli neşrinde de Riyâzî-yi Üskübî’ye dair 
okuyucu/bilgi notları Rıdvan Canım tarafından "asıl metinle ilgisi olmayıp müstensih tarafından eklendiği" gerekçesiyle metne dâhil edilmemiştir (Canım, 2000, s. 692). Her ne kadar notların kime ait olduğunu tahmin niyetiyle olmasa da Rıdvan Canım'ın bu vurgusundan Riyâzî̀ye dair bu notların Râşid Efendi nüshasının "müstensih"i tarafından tutulduğu sonucunu çıkarmak mümkündür. Ayrıca Latîfî Tezkiresi'nin sadeleştirilmiş metnini yayınlayan Mustafa İsen de çalışmasına esas olarak Kayseri Râşid Efendi Kütüphanesindeki nüshayı almasına rağmen Riyâzî-yi Üskübî’ye dair bu notları metne almamış ve Râşid Efendi'nin tezkire kısmında bulunmayan Riyâzî-yi Üskübî maddesini farklı bir nüshadan temin etmiştir (İsen, 1999, s. 370-71).

\section{3. Şems-i Dervîş örneği ve bilgi/okuyucu notlarının güvenilirliği meselesi}

Daha önceden sırası geldiğinde Râşid Efendi'deki notların dönemin diğer tezkirelerine ne derece yansıdıkları üzerinde durulmuştu. Bu başlık altında ise notlardaki bilgilerin güvenilirliğini Şems-i Dervîş (Şemsî-yi Dervîş/ Dervîş Şemsî) özelinde biraz detaylandırmak istiyoruz. Hatırlanacak olursa Râşid Efendi nüshasının "tezkire" kısmında Şems-i Dervîş'in, Sultan Selim dönemi şairlerinden olup Deh Murg'u ona ithaf ettiği ve sultandan büyük ihsanlar gördüğü kayıtlıyken bu nüshanın "derkenar" kısmında Latîfî́nin verdiği bu malumatın yanlış olduğu vurgulanıp Şems-i Derviş̧'in Sultan Süleyman dönemi şairlerinden olduğu ve meşhur eseri Deh Murg'ı Sultan Süleyman'a sunduğu kayıtlıdır. Burada bizi ilgilendiren husus Şems-i Dervîş'in hangi dönemde yaşadığı ve eserini kime sunduğu değil, hangi rivayetin doğru olduğudur. Şayet Latîfí'nin rivayeti doğruysa Râşid Efendi'deki notların güvenilirliği hususunda ciddi soru işaretleri oluşacak ve bu da kimi şairlere dair satır arası bilgiler veren bu notların değerini azaltacaktır. Tam tersi durumda ise notların kıymeti artacaktır. Tıpkı Latîfî gibi şairi tezkiresine alan o dönem tezkirecilerinin Şems-i Dervîş'in hangi sultan döneminde yaşadığı ve Deh Murg'u kime sunduğu sorularına verdikleri cevaplar aşağıdaki tabloda gösterilmiştir. Şems-i Dervîş maddesinin bulunmadığ tezkirelere tabloda yer verilmemiştir:

Tablo-3: Râş̧id Efendi nüshasındaki Şems-i Derviş̧'e dair bilgi notunun dönemin tezkireleriyle mukayesesi

\begin{tabular}{|l|l|l|l|l|l|}
\hline & $\begin{array}{c}\text { Râşid Efendi } \\
\text { nüshasının } \\
\text { derkenarındaki } \\
\text { notlar }\end{array}$ & $\begin{array}{c}\text { Raşid } \\
\text { Efendi } \\
\text { nüshasının } \\
\text { tezkire kısmı }\end{array}$ & $\begin{array}{c}\text { Latîfî̀ } \\
\text { Tezkiresi'nin } \\
\text { Hâlet Efendi } \\
\text { nüshası }\end{array}$ & $\begin{array}{c}\text { Âşık } \\
\text { Çelebi } \\
\text { Tezkiresi }\end{array}$ & $\begin{array}{c}\text { Hasan } \\
\text { Çelebi } \\
\text { Tezkiresi }\end{array}$ \\
\hline $\begin{array}{l}\text { Tezkirelerde Şems-i Dervîş } \\
\text { hangi sultan döneminin şairi } \\
\text { olarak gösterilmiştir? }\end{array}$ & Süleyman & Selim & Selim & Selim & Selim \\
\hline $\begin{array}{l}\text { Şems-i Dervisş, Deh Murg'u } \\
\text { kime sunmuştur? }\end{array}$ & Süleyman & Selim & Selim & Selim & Selim \\
\hline
\end{tabular}

Tablodan anlaşılacağı üzere Şems-i Dervîş'i Sultan Süleyman'la ilişkilendiren tek metin Râşid Efendi nüshasındaki okuyucu notlarıdır. Gerek Âşık Çelebi gerekse Kınalızâde Hasan Çelebi bu bağlamda Latîfî̀nin rivayetini tekrarlamaktadır. Bu açıdan bakınca Dervîş Şemsî̀ye dair doğru bilgiyi veren "notlar" değil Latîfî gibi gözükmektedir. Ancak Râşid Efendi nüshasına bu notu düşen kişinin üstüne basa basa Latîfî́nin hata yaptığını vurgulamasının bir mantık ve dayanağı olması gereklidir. Derkenardaki okuyucu notuna yeniden baktığımızda Deh Murg'un Şems-i Dervîş tarafından Rodos ve Engürüs'ün fethini müteakip Sultan Süleyman'a sunuluşundan bahsedildiği görülmektedir. Notta göze çarpan 
bir diğer husus ise Deh Murg'un sebeb-i telîf kısmında Sultan Selim'in ölümü için şairin epeyce üzüldüğü ve tahta Sultan Süleyman'ın çıkışı ile teselli bulduğu şeklindeki bilgidir (Râşid Efendi, yz. 1160, 95a). Notların musannifi bu iddiasını Deh Murg'a dayandırdığına göre iddianın teyit yahut tekzibi de ancak Deh Murg vasıtasıyla mümkündür. Bu bağlamda Deh Murg'a bakıldığında eserin birçok nüshasında Sultan Selim medhinin bulunduğu görülecektir. Fakat -Deh Murg'u neşreden Mahmut Kaplan'ın (2003, s. 54) da tespit ettiği üzere- Bibliotheque Nationale Suplement Turc 393 olarak Fransa'da kaytlı bir Deh Murg nüshasında Sultan Selim'in yerini Sultan Süleyman almaktadır. ${ }^{6}$ Tıpkı Râşid Efendi'deki okuyucu notunda belirtildiği üzere bu nüshanın sebeb-i te'lîf kısmının ilk dokuz beytinde Sultan Selim'in ölümünden duyulan üzüntü ve sonraki beş beytinde ise Sultan Süleyman'ın tahta geçişinden duyulan memnuniyet net bir biçimde dile getirilmektedir:

Sebeb-i te'lîf-i kitâb

(...)

[3b] 1. Göz yaşından bâde bagrumda kebâb

Derd-i dilden nukl-1 efgânum rebâb

2. Râh-1 Hakk'a eyleyüp kanum sebîl

Üstühânum şem‘ magzıydı fetîl

3. 'Işkıla yakdum yüregüm yagını

Rûşen itdüm bu vücûdum bâgını

4. Bahr-1 fikret mevc uruban kıldı cûş

Eyledi hum-hâne 'aklumı hurûş

5. Fikre vardum 'ibretile bir zamân

Kim ne zecr itdi Selîm Han'a cihân

6. Aldı elden mâl u milkin ser-te-ser

Cismi şehrin eyledi zîr ü zeber

7. Kanı az günde anun çok işleri

Rüstem-i Destân gibi cünbişleri

8. Gitdi bir demde olup cümle tebâh

Âh elünden ey cihân-ı rû-siyâh

9. Fevtine olan kişiler sâmi ‘ûn

Didiler innâ ileyhi râci 'ûn

10. Gitdi ise n'ola ol şâh-1 cihân

Bâki olsun milk-i Süleymân-zamân

11. Öldi sanmanuz siz anı diridür

Çünki tahtı şeh Süleymân yiridür

[4a] 1. Şöyle kim bir pâdşehdür şîr-i ner

${ }^{6}$ Deh Murg'un bu nüshasını temin için kıymetli vaktini ayıran Mehmet Büküm'e ve eserin tenkitli neşrine ulaşmamda yardımcı olan Abdülkadir Dağlar'a teşekkür ederim.

SEFAD, 2020; (44): 161-180 
Anda hatm olmış durur cümle hüner

2. Çün zamân el virdi 'irfân devridür

Hazret-i Sultân Süleymân devridür

3. Bârı hoş-bûsından anun gül-'izâr

Açllup her yirde irmişdür bahâr

(Şemsî-yi Dervîş, yz. 393, 3b-4a)

Yukarıdaki kısmın yanı sıra aynı nüshanın Sıfat-ı Bahâr bölümünün son beytinde "Süleyman" ismi zikredilip onun tahta çıkışından duyulan mutluluk:

Müjdegân virsün dile cân-1 cihân

Sâye saldı çün Süleymân-ı zamân

şeklinde dile getirilmekte ve hemen sonrasında Sultan Süleyman medhini muhtevi DerMedh-i Pâdişâh adlı bir bölüm başlamaktadır. Ancak bu bölüm Deh Murg'un diğer nüshalarında Kasîde Der-Medh-i Selîm Han, Der-Mehâmid-i Sultân Selîm gibi başlıklarla Sultan Selim adına tanzim edilmiştir. Kaplan'ın (2003, s. 73) Deh Murg neşrine göre kimi nüshalarda:

Heybetinde Rüstem-i Destândur

Nâm-1 'izzetde Selîm Sultândur

kimi nüshalardaysa:

Pâdişâh-1 Husrev-i devrândur

Her kemâlile Selîm Sultândur

biçimlerinde Sultan Selim ismiyle geçen beyit Bibliotheque Nationale Suplement Turc 393 $5 a^{\prime} d a$ :

Heybetiyle Rüstem-i Destândur

Nâm-1 'izzetde Süleymân Hândur

şeklinde Sultan Süleyman adıyla geçmektedir. Sultan Selim'in geçtiği nüshalarda olmayıp da Fransa'daki nüshanın 5a'sında bulunan:

Kılıcından feth olındı Engürüs

Döymedi bir darbına şehr-i Rodos

beyti de Râşid Efendi nüshasındaki notlarda vurgulanan Şems-i Dervîş'in Deh Murg'u Engürüs ve Rodos'un fethinden sonra Sultan Süleyman'a sunduğu iddiasını desteklemektedir. Deh Murg'un birçok nüshasındaki kayıtlar eserin Sultan Selim'e sunulduğunu desteklerken Fransa'daki nüshanın Sultan Süleyman'ı işaret etmesi gerçekten anlaşılması zor bir durumdur. Şems-i Dervîş şayet ki Sultan Süleyman'ın bahsi geçen iki fethinden sonra hâlâ yaşıyorsa bazı ekleme ve çıkarmalarla mesnevisini Sultan Süleyman'a da sunmuş olabilir. Bibliotheque Nationale nüshasındaki bu kayıtlar ortada olduğu sürece gerek tezkirelerin Şems-i Derviş'e dair söyledikleri gerekse Deh Murg'un birçok nüshasında Sultan Selim isminin bulunuyor oluşu Râşid Efendi nüshasındaki iddiayı çürütmek için yeterli değildir. Şu durumda Râşid Efendi'deki notlar -en azından Şems-i Dervîş özelindearka planda bazı kaynaklara dayandığından güvenilirliği hususunda kesin bir şey söylenemese de tamamen yokmuş gibi de kabul edilemez. 


\section{SONUÇ}

Râşid Efendi'de kayıtlı Latîfî nüshası, tüm bu örnek ve iddialar çerçevesinde derkenardan okunduğunda muğlak da olsa aşağıdaki sonuçlara ulaşmak mümkündür:

i) Râşid Efendi nüshasının derkenarlarında sahh kaydı ve bilgi/okuyucu notu olmak üzere iki tür kayıttan bahsetmek gereklidir. Bunlardan sahh kayıtlarının tezkirenin genişletilmiş versiyonunda yer aldığı gözlemlenirken okuyucu notu olarak isimlendirdiğimiz notların genişletilmiş versiyonda bulunmadığı anlaşılmıştır. Bu da okuyucu notlarının tezkirenin organik yapısıyla bütünlük içinde olmadığının göstergesidir. Latîfî Tezkiresi neşirlerinin notları metne dâhil etmemeleri bu bağlamda isabetlidir. Zira bunlar müstakil ve özgün bir görünümdedir.

ii) Râşid Efendi'deki bu notlar bir bütün olarak Latîfî tarafından kaynak alınmadığı gibi devrin diğer tezkireleri tarafından da alınmış değildir.

iii) Notların kime ait olduğu hususunda da çeşitli tahmin yahut iddialar gündeme getirilmiştir. Râşid Efendi nüshasında derkenar olarak yer alan Riyâzî-yi Üskübî maddesinden hareketle notların Latîfî'ye ait olabileceği öne sürülmüştür. Ancak bazı notlarda doğrudan Latîfi'yi hedef alan: "Mü'ellif hazretleri Mevlânâ Latîfi burada sehv itmişlerdür// Mü'ellif hazretleri mücerred nisbet itdügünden hatâ itmişdür. Kavli dahı mu 'temed degüldür// Latîfi bun idrâk u zabt itmekde kâsır oldugıçün hakîr yazdum." tarzındaki ifadeler notların Latîfí'ye ait olma ihtimalini epeyce zayıflatmaktadır.

iv) Notların kime ait olduğuna dair bir diğer tahmin ise bunların Râşid Efendi nüshasının müstensihine ait olabileceği yönündedir. Ancak buna Râşid Efendi nüshasının hâtimesinde karşımıza çıkan hicrî 953 yılı ile notların hicrî 957'de düşüldüğünü gösteren arka kapak zahriyedeki kayıt engel teşkil etmektedir.

v) Râşid Efendi nüshasının arka kapak zahriyesinde vurgulandığı üzere bu notlar bir "ârif-i avârif-nisâb" diye nitelenen biri tarafından tutulmuş ve tezkireye de yine şu an için kim olduğunu bilmediğimiz biri tarafından eklenmiştir. Notların yazıldığı yılı gösteren arka kapak zahriyedeki hicrî 957 yılı ile ön kapak zahriyedeki hicrî 957 tarihli temellük kaydından hareketle söylenecek olursa notların kâtibi ile temellükte adı geçenin aynı kişi olması muhtemeldir. Bununla birlikte notların müellifine dair şu an için bir şey söylemek zordur. Ancak her ne kadar kim olduğuna dair bir tespitte bulunma imkânımız olmasa da Latîfî́nin eksik ve yanlışlarını sıralayan bu kişinin alelâde biri olmayıp entelektüel açıdan donanımlı ve tezkire kültürüne hâkim biri olduğunu söylemekte sakınca yoktur. Diğer taraftan Türk tezkirecilik geleneğinin yeni yeni oluşmaya başladığı bir dönemde Latîfí'yi inceden inceye okuyup eksik ve yanlışlarını sıralayanların varlığı bu geleneğe gösterilen ilginin de bir tür işareti olsa gerektir.

vi) Notların sahibinin böyle bir donanımda olması, bunların o dönem tezkirecilerinin biri tarafından kaleme alınma ihtimalini akla getirse de 16'ncı yüzyıl tezkirelerinin hemen hemen hiçbiri önemli ölçüde notlardaki bilgileri eserlerine taşımadığından bu ihtimal zayıftır.

vii) Râşid Efendi nüshasındaki derkenarların ne derece muteber oldukları ve bir çırpıda göz ardı edilip edilemeyeceği hususu da bu çalı̧̧mada ele alınanlardandır. Şems-i Dervîş (Şemsî-yi Dervîş) örneğinde görüldügüü üzere, dönemin bütün tezkireleriyle tenakuz halinde olduğu konularda dahi hatalı bilgiler aktardığı gerekçesiyle derkenarlardaki bilgi/okuyucu notlarının üstünü bir kalemde çizmek kolay değildir. 


\section{SUMMARY}

Latifi's Tezkere, which is regarded as one of the important sources of the sixteenthcentury biography and prose traditions, could not escape from being the target of various criticisms, starting from the first years when it was written. However, it is not possible to say that these notes, written on the apostil (derkenar) of the said copy, were kept only for opposition to Latifi because these notes are complementary to the biographical personalities that Latifi deals with by considering various aspects. These notes in Rashid Efendi copy provide examples of poems that Latifi could not detect in some cases, and in some cases, they provide inline information about some poets. In a few examples, it is seen that the person holding the notes directly targeted the author of the tezkere with phrases such as "Latifi, müellif hazretleri and Monla Latifi". In the notes containing such addresses, it was attempted to correct the mistakes of Latifi and it was emphasized that the information given by the author was not reliable.

The aforementioned notes are spread over the entire text. It is not entirely clear who kept these notes that were recorded in the copy of Rashid Efendi. However, some studies on this copy, which was accepted as the first version of the tezkere, claimed that the person who wrote the notes might have been Latifi. The apostils (derkenar) in Rashid Efendi's copy are not in the form of reader notes. For this reason, the apostils (derkenar) in the copy are divided into two, as "sahh records" and "reader notes" in the introduction part of the article. After focusing on Sahh records, the main subject was presented and the reader notes in the copy of Rashid Efendi were examined under the following titles: "Reader notes in Rashid Efendi and their characteristics" "Why are the notes written?", "Do the notes belong to Latifi?", "The question of the reliability of the notes". The issue of whether the reader notes in the copy of Rashid Efendi are the source of the copy of Halet Efendi, which is accepted as an extended version of the Latifi's Tezkere, and the other tezkere of the period, is another issue discussed in the article.

Makale Bilgileri

\begin{tabular}{ll}
\hline Etik Kurul Kararı: & Etik Kurul Kararından muaftır. \\
Katılımcı Rızası: & Katılımcı yoktur \\
Mali Destek: & Çalışma için herhangi bir kurum ve projeden mali destek alınmamıştır. \\
Çıkar Çatışması: & Çalışmada kişiler ve kurumlar arası çıkar çatışması bulunmamaktadır. \\
Telif Hakları: & Çalışmada kullanılan görsellerle ilgili telif hakkı sahiplerinden gerekli \\
& izinler alınmıştır.
\end{tabular}

Article Information

$\begin{array}{ll}\text { Ethics Committee Approval: } & \text { Exempt from the Ethics Committee Decision. } \\ \text { Informed Consent: } & \text { No participants. } \\ \text { Financial Support: } & \text { No financial support from any institution or project. } \\ \text { Conflict of Interest: } & \text { No conflict of interest. } \\ \text { Copyrights: } & \text { The required permissions have been obtained from the copyright holders } \\ & \text { for the images and photos used in the study. }\end{array}$




\section{KAYNAKÇA}

Ahmed Cevdet (1314). Âsâr-ı eslâfdan tezkire-yi Latîfî. Dersaâdet: İkdâm Matbaası.

Andrews, W. G. \& Dalyan, A. (2019). İki farklı Latifi Tezkiresi ve nüshaları. Türk Dili Araştırmaları Yıllı̆̆ı-BELLETEN, 68, 49-68. doi: 10.32925/tday.2019.30.

Andrews, W. G. (1970). The tezkere-i şuarâ of Latîfi as a source for the critical evaluation of Ottoman poetry (Yayımlanmamış doktora tezi). University of Michigan, Michigan.

Andrews, W. G. (1996). Metin nerede? Hangi metin? Kimin metni?. Varlik, 1062, 46-50.

Andrews, W. G. (2015). Osmanlı metin çalışmaları: Geçmişe meydan okuma, geleceği tasarlama. (Veysel Öztürk, Çev.). H. Aynur, M. Çakır, H. Koncu, S. S. Kuru \& A. E. Özyıldırım (Haz.), Eski Metinlere Yeni Bağlamlar: Osmanlı Edebiyatı Çalışmalarında Yeni Yönelimler içinde (s. 36-58). İstanbul: Klasik Yay.

Canım, R. (2000). Latîfî tezkiretü'ş-şu'arâ ve tabsıratü'n-nuzamâ: İnceleme-metin. Ankara: Atatürk Kültür Merkezi Yayınları.

Dalyan, A. (2020, 2 Şubat). Latifi projesi ve Latîfî Tezkiresinin iki farklı yazmasında Mihrî ile Zeyneb maddelerinin karşılaştırılması. Erişim adresi: https://www.academia.edu/39902796/LAT\%C4\%B0F\%C4\%B0_PROJES\%C4\%B0VE_LA \%E1\%B9\%AC\%C4\%AAF\%C4\%AATEZK\%C4\%B0RES\%C4\%B0N\%C4\%B0N_\%C4\%B0K \%C4\%B0_FARKLI_YAZMASINDA_M\%C4\%BOHR\%C4\%AA_\%C4\%BOLE_ZEYNEB_M ADDELER $\%$ C4\%B0N\%C4\%B0N_KAR\%C5\%9EILA\%C5\%9ETIRILMASI.

Değirmenci, T. (2011). Bir kitabı kaç kişi okur? Osmanlı'da okurlar ve okuma biçimleri üzerine bazı gözlemler. Tarih ve Toplum Yeni Yaklaşımlar, 13, 7-43.

İpekten H., Kut, G., İsen, M., Atay, H. \& Karabey, T. (2017). Seĥ̂ Beg heşt bihişt. https://ekitap.ktb.gov.tr/Eklenti/56165,hestbihistpdf.pdf?0\&_tag1=03EE5380B678F1063B F0A9ED54D2FA0DD771F0E5\&crefer=128EED3CA597181B3BC837ADF08564A36D698D 0D973D489829C80B43861853D2. Erişim tarihi: 02.02.2020.

İsen, M. (1994). Künhü'l-ahbârın tezkire kısmı. Ankara: Atatürk Kültür Merkezi Yayınları.

İsen, M. (1999). Latîfî Tezkiresi. Ankara: Akçağ Yayınları.

Kaplan, M. (2003). Deh murg-ı Şemsî: İnceleme-metin-sözlük. Manisa Celal Bayar Üniversitesi Yükseköğrenim Vakfı Yay.

Kılıç, F. (2010). Âşık Çelebi meşâ iriü'ş-şu ‘arâ: İnceleme-metin. İstanbul: İstanbul Araştırmaları Enstitüsü Yayınları.

Kutluk, İ. (1989). Kınalı-zade Hasan Çelebi tezkiretü'ş-şuarâ. Ankara: Türk Tarih Kurumu Basımevi.

Latîfî. Tezkiretü'ş-şu 'arâ. Kayseri Raşid Efendi Kütüphanesi. 1160.

Latîfî. Tezkiretü'ş-şu 'arâ. Süleymaniye Kütüphanesi. Hâlet Efendi, 342.

Latîfî. Tezkiretü'ş-şu 'arâ. Süleymaniye Kütüphanesi. Kılıç Ali Paşa, 780.

Solmaz, S. (2005). Ahdî ve gülşen-i şu 'arâsı: İnceleme-metin. Ankara: Atatürk Kültür Merkezi Başkanlı̆̆1 Yayınları.

Sungurhan, A. (2017). Kınalızâde Hasan Çelebi Tezkiretü'ş-şu 'arâ. https://ekitap.ktb. gov.tr/TR194494/kinalizade-hasan-celebi-tezkiretus-s-uara.html. Erişim tarihi: 02.02.2020.

Şemsî-yi Dervîş. Deh murgân. Bibliotheque Nationale Suplement Turc. 393.

SEFAD, 2020; (44): 161-180 
Ek-1: Kayseri Râşid Efendi Kütüphanesi 1160 numarada kayıtlı nüshanın arka kapak zahriyesi: Râşid Efendi, yz. 1160, 165b.

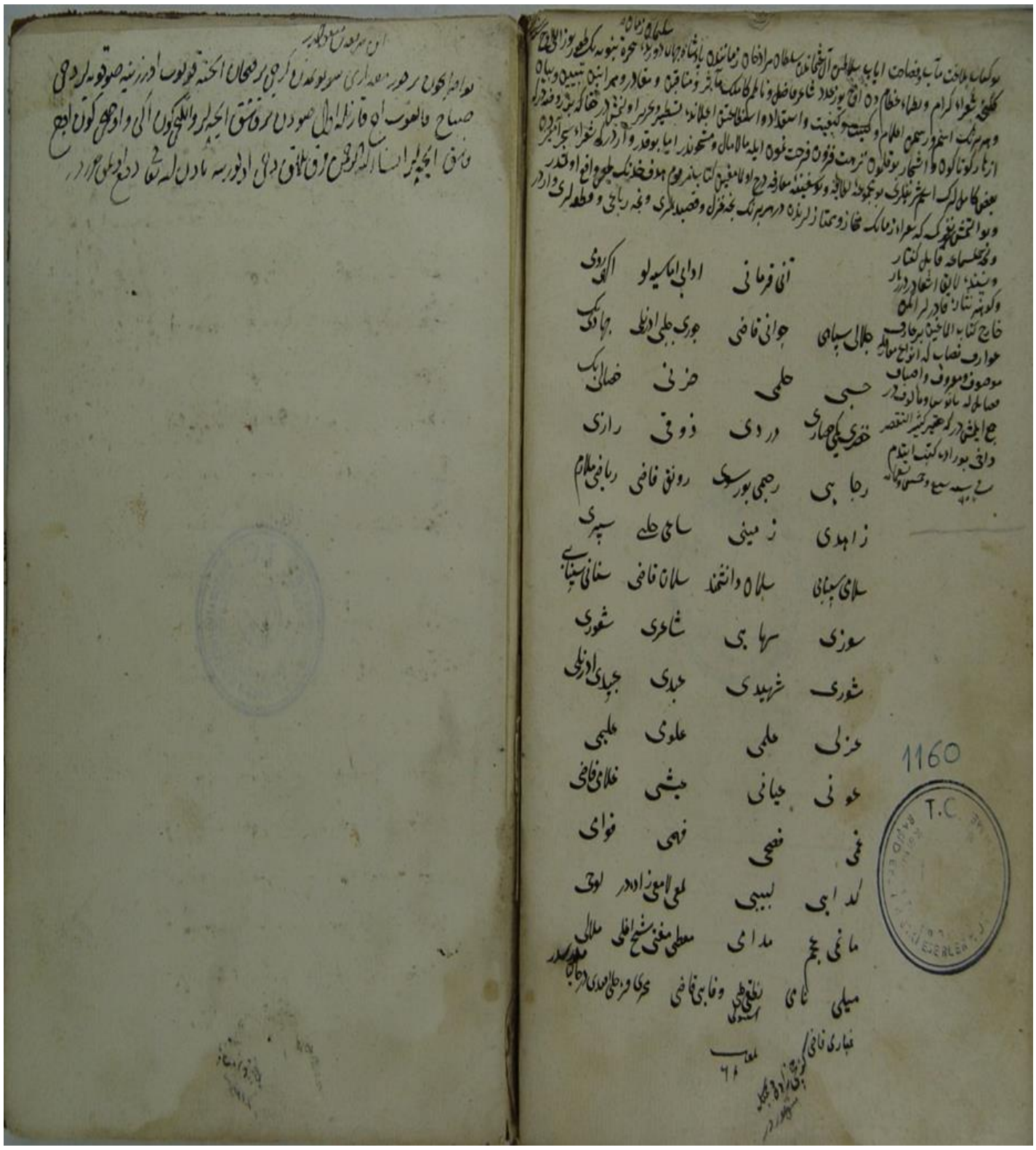

